\title{
PERSEPSI GURU TENTANG KEPEMIMPINAN TRANSFORMASIONAL KEPALA SEKOLAH, TRANSPARANSI, DAN AKUNTABILITAS PENGELOLAAN KEUANGAN SEKOLAH
}

\author{
Johan Pitoyo Jati Karyono \\ Guru SMAN 6 Madiun
}

\begin{abstract}
This study aims to: 1) the effect of teachers' perceptions of transformational leadership principals to the transparency of financial management of the school;2) knowing effect perseptions teacher of transformational leadership principals to the accountability of financial management school. Population this research is all public school teachers SMA/SMK/MA in Madiun city. Method sampling technique used is sampling produce purpusive sample of 120 responden. Method analysis used in this study is the linear regression analysis simple. Result tests performed showed that perseption head teacher of transformational leadership school dan positive effect on the transparency of financial management of the school; 2) teachers' perceptions of transformational leadership principals positive effect on financial management accountability school.
\end{abstract}

Keywords: Transformational leadership, transparency, accountability, financial management of the school.

\begin{abstract}
Abstrak: Penelitian ini bertujuan: 1) mengetahui pengaruh persepsi guru tentang kepemimpinan transformasional kepala sekolah terhadap transparansi pengelolaan keuangan sekolah; 2) mengetahui pengaruh persepsi guru tentang kepemimpinan transformasional kepala sekolah terhadap akuntabilitas pengelolaan keuangan sekolah. Populasi penelitian ini adalah semua guru sekolah negeri tingkat SMA/SMK/MA di Kota Madiun. Metode pengambilan sampel yang digunakan adalah teknik purpusive sampling menghasilkan sampel sebanyak 120 responden. Metode analisis yang digunakan dalam penelitian ini adalah analisis regresi linier sederhana. Hasil pengujian yang dilakukan menunjukkan bahwa persepsi guru tentang kepemimpinan transformasional kepala sekolah dan berpengaruh positif terhadap transparansi pengelolaan keuangan sekolah; 2) persepsi guru tentang kepemimpinan transformasional kepala sekolah berpengaruh positif terhadap akuntabilitas pengelolaan keuangan sekolah.
\end{abstract}

Kata kunci: Kepemimpinan transformasional, transparansi, akuntabilitas, pengelolaan keuangan sekolah.

\section{PENDAHULUAN}

Diberlakukannya Undang-Undang No. 32 Tahun 2004 tentang Pemerintahan Daerah, salah satu perubahan yang mendasar di dunia pendidikan yaitu sistem manajemen yang sentralistik menjadi sistem manajemen desentralistik, hal ini menuntut adanya penyesuaian dan perubahan dalam pengelolaan organisasi sekolah. Demikian juga seperti yang dinyatakan Onorato (2013) bahwa gerakan reformasi yang melanda dunia juga melanda reformasi di dunia pendidikan yang dalam pengelolaannya seperti pada dunia bisnis di industri. Perubahan tersebut tentunya mempengaruhi kepemimpinan kepala sekolah. Ling dan Ibrahim (2013) menyatakan kepemimpinan sekolah telah menjadi prioritas dalam agenda kebijakan pendidikan 
internasional, memainkan peran penting dalam meningkatkan kinerja sekolah dengan mempengaruhi motivasi, kemampuan guru, iklim, dan lingkungan sekolah.

Hallinger (2003) menyatakan bahwa kepemimpinan transformasional merupakan gambaran kepemimpinan yang sangat ideal di sekolah. Onorato (2013) dalam penelitiannya mengemukakan bahwa dengan kepemimpinan transformasional di sekolah dapat mengubah status quo dengan kerangka kepemimpinan yang mirip dengan pemimpin perusahaan bisnis dalam mengelola industri swasta yang meliputi pengelolaan personil, pengendaliaan anggaran, penetapan tujuan strategis dan bekerja sama dengan kekuatankekuatan eksternal, serta penempatan akuntabilitas pada sektor pendidikan.

Dari uraian di atas maka kepemimpinan transformasional adalah kepemimpinan yang akan mendorong tumbuhnya perilaku individu yang dipimpinnya ke arah perubahan yang diinginkan. Hal ini juga didukung oleh pendapat dari Hall, Johnson, Wysocki, dan Kepner (2012) bahwa ada empat faktor kepemimpinan transformasional, dikenal sebagai "empat I", yaitu idealized influence (pengaruh idealis), inspirational motivation (motivasi inspirasional), intellectual stimulation (stimulasi intelektual), dan individual consideration (pertimbangan individu).

Akuntabilitas adalah mempertanggungjawabkan pengelolaan sumber daya serta pelaksanaan kebijakan yang dipercayakan kepada entitas pelaporan dalam mencapai tujuan yang telah ditetapkan secara periodik.

Penelitian masalah akuntabilitas dan transparansi di sektor pendidikan telah banyak dilakukan. Misalnya, Eric dan Margaret (2006) menyatakan bahwa akuntabilitas berkaitan dengan tiga hal yakni efek ekonomi, prestasi, dan memperbaiki kesenjangan. Lee dan McWilliam (2007) menyatakan bahwa akuntabilitas dan responsibilitas berpengaruh terhadap pengelolaan pembelajaran di sekolah. Boy dan Siringoringo
(2009) menyatakan bahwa ada tuntutan akuntabilitas publik dan transparansi dalam pengelolaan keuangan sekolah. Demikian juga, Anggraini (2013) menyatakan bahwa ada hubungan antara transparansi dan partisipasi, dengan akuntabilitas dalam program RKAS.

Namun masalah akuntabilitas dan transparansi masih menjadi topik yang menarik. Seperti SMA Negeri 2 Kendal, SMA Negeri 1 Ngunut, Tulungagung, SMA Negeri 3 Kabupaten Pamekasan, mogok belajar dan mendemo kepala sekolah dan jajarannya agar mundur dari jabatan mereka, dan aksi tersebut merupakan rangkaian mosi ketidakpercayaan kalangan dewan guru dan siswa terhadap kinerja kepala sekolah, wakasek, bendahara insidental, dan bendahara rutin. Puluhan siswa. Demikian juga di harian Jawa Pos (2014). Rabu, 19 Maret 2014 memuat bahwa mantan Kepala Sekolah SMA Negeri 1 Madiun dan mantan Kepala Sekolah SMA Negeri 5 Madiun telah dituntut 5 tahun penjara, mengganti uang kerugian negara dan pidana denda oleh Pengadilan Tipikor Surabaya. Dari semua kejadian di atas diduga kepala sekolah dalam mengelola keuangan sekolah tidak melaksanakan transparansi dan akuntabilitas seperti yang diharapkan oleh standar yang berlaku ataupun oleh stakeholders sekolah.

Berangkat dari latar belakang masalah di atas, maka penelitian ini diajukan dengan judul: "Persepsi Guru Tentang Kepemimpinan Transformasional Kepala Sekolah, Transparansi, dan Akuntabilitas Pengelolaan Keuangan Sekolah".

\section{Landasan Teori}

Kepemimpinan merupakan salah satu aspek yang paling penting dari manajemen. Kepemimpinan kepala sekolah dalam satuan pendidikan dituntut untuk menjabarkan visi pendidikan nasional serta mewujudkan transparansi dan akuntabilitas dalam pengelolaan keuangan sekolah. Kepemimpinan kepala sekolah sangat menentukan hal tersebut. 


\section{Kepemimpinan Transaksional}

1. Pengertian Kepemimpinan Transaksional

Bycio, Hackett, dan Allen (1995) serta

Koh, Streers, dan Terborg (1995) menyatakan bahwa kepemimpinan transaksional adalah kepemimpinan seorang pemimpin yang memfokuskan perhatiannya pada transaksi interpersonal antara pemimpin dengan karyawan yang melibatkan hubungan pertukaran. Menurut Burns (1978) bahwa kepemimpinan transaksional didasarkan pada otoritas birokrasi dan legitimasi dalam organisasi.

Secara mendasar, kelebihan kepemimpinan transaksional adalah dapat memotivasi bawahan secara individu dan meningkatkan kinerja pegawai secara individu. Sedang kelemahan pemimpinan transaksional adalah munculnya persaingan individu dalam sebuah lembaga.

2. Karakteristik Kepemimpinan Transaksional

Odumeru dan Ogbonna (2013) menuliskan bahwa karakteristik kepemimpinan transaksional, yaitu kepemimpinan yang mempertahankan status quo, kepemimpinannya adalah responsif, karyawan bekerja dalam budaya organisasi, karyawan mencapai tujuan melalui imbalan dan hukuman yang ditetapkan oleh pemimpin, pemimpin memotivasi pengikut untuk kepentingan diri sendiri serta penekanan untuk meningkatkan kinerja.

\section{Kepemimpinan Transformasional}

1. Pengertian Kepemimpinan Transformasional

Secara definisi, pemimpin transformasional adalah pemimpin yang terampil dalam memimpin (leading), memperjuangkan perubahan (championing change), dan mengubah organisasi (transforming organizations) (Warrick, 2011). Keller (1992) mengemukakan bahwa kepemimpinan transformational adalah sebuah kepemimpinan yang mengutamakan pemenuhan terhadap tingkatan tertinggi dari hierarki Maslow yakni kebutuhan akan harga diri dan aktualisasi diri. Adanya pemenuhan kebutuhan tersebut sejalan dengan hasil penelitian yang dilakukan Simic (1998) yang menyatakan bahwa kepemimpinan transformasional memiliki atribut: kreativitas, orientasi tim, apresiasi, pengaruh, tanggung jawab, dan pengakuan.

Secara mendasar keterampilan pemimpin transformasional dijelaskan sebagai berikut (Warrick, 2011).

\section{a) Leading}

Leading terdiri dari 3 poin penting, yaitu: 1) the process of providing vision, 2) direction, dan 3) inspiration (Warrick, 2011). Pemimpin harus mewujudkan visinya. Visi seorang pemimpin dikomunikasikan dalam hal tujuan (apa yang perlu dilakukan), nilainilai (bagaimana hal-hal yang harus dilakukan), dan prioritas (yang paling penting).

\section{b) Championing change}

Championing change dideskripsikan sebagai kemampuan dalam initiating, facilitating, and implementing change.

\section{c) Transforming organizations}

Transforming organizations dideskripsikan sebagai sebuah: a) proses mengetahui realitas sekarang (knowing present realities); b) mengidentifikasi kondisi ideal masa depan (identifying future ideals); dan c) mengembangkan serta mengimplementasikan sebuah proses untuk mentransformasi organisasi (developing and implementing a process for transforming organizations) (Warrick, 2011).

2. Karakteristik Kepemimpinan Transformasional

Sarros dan Butchatsky (1996) menyatakan model kepemimpinan transformasional merupakan konsep kepemimpinan yang terbaik dalam menguraikan karakteristik pemimpin sehingga para pemimpin kita lebih berkerakyatan dan berkeadilan sosial. Kelebihan kepemimpinan transformasional mempunyai dibandingkan dengan kepemimpinan transaksional, yaitu: a) agen perubahan 
kualitas; b) keberanian untuk mengambil risiko; c) keterbukaan para pengikut; d) nilainilai kepemimpinan; e) belajar seumur hidup; f) kemampuan untuk menghadapi situasi yang kompleks, ambigu dan tidak pasti; dan g) kemampuan visioner (Simic, 1998). Odumeru dan Ogbonna (2013) menambahkan bahwa kepemimpinan transformasional adalah kepemimpinan proaktif. Karakter proaktif tersebut ditunjukkan dengan pemimpin: bekerja untuk mengubah budaya organisasi dengan menerapkan ide-ide baru, karyawan mencapai tujuan melalui cita-cita yang lebih tinggi dan nilai-nilai moral, pemimpin memotivasi pengikut dengan mendorong mereka untuk menempatkan kepentingan kelompok sebagai yang pertama, pemimpin memberi pertimbangan dan dukungan untuk mengekspresikan perilaku setiap individu, dan pemimpin mempromosikan ide-ide kreatif dan inovatif untuk memecahkan masalah.

\section{Kepemimpinan Kepala Sekolah}

Hall et al. (2012) mendefinisikan kepemimpinan yang efektif adalah sebagai suatu proses satu individu mempengaruhi sekelompok individu yang lain untuk mencapai tujuan bersama dalam organisasi. Undang-Undang Nomor 32 Tahun 2004 tentang Pemerintahan Daerah, mengakibatkan adanya salah satu perubahan yang mendasar dalam organisasi pendidikan yaitu sistem manajemen yang sentralistik menjadi sistem manajemen desentralistik. Dharma (2003: 2) menegaskan bahwa kepemimpinan kepala sekolah mengacu pada kualitas tertentu yang harus dimiliki kepala sekolah untuk dapat mengemban tanggung jawabnya. Kualitas yang dimaksud adalah mengetahui visi dan misi; memiliki kompetensi untuk melaksanakan misi guna mewujudkan visi; dan memiliki karakter yang menunjukkan integritasnya.

\section{Pengelolaan Keuangan Sekolah}

Undang-undang Nomor 20 Tahun 2003 pasal 48 menyatakan bahwa pengelolaan dana pendidikan perlu memperhatikan sejumlah prinsip yakni prinsip keadilan, efisiensi, transparansi, dan akuntabilitas publik. Salama, Catheart, Andrews, dan Hall (2006) yang mengungkapkan bahwa untuk mencapai reformasi pendidikan dalam rangka meningkatkan lembaga dibutuhkan transparansi dan akuntabilitas dalam laporan keuangan.

1. Transparansi

Transparansi adalah keterbukaan atas semua tindakan dan kebijakan yang diambil oleh pemerintah (Hamid, 2007). Prinsip transparansi menciptakan kepercayaan timbal-balik antara pemerintah dan masyarakat melalui penyediaan informasi dan menjamin kemudahan di dalam memperoleh informasi yang akurat dan memadai.

Transparansi keuangan sangat diperlukan dalam rangka meningkatkan dukungan orang tua, masyarakat dan pemerintah dalam penyelenggaraan seluruh program pendidikan di sekolah. (Dharma, 2007).

Dalam konteks pendidikan, istilah transparansi sangatlah jelas yaitu kepolosan apa adanya, tidak bohong, jujur, dan terbuka terhadap publik tentang apa yang dikerjakan oleh sekolah (Hamid, 2007).

a. Tujuan Transparansi

Transparansi bertujuan untuk menciptakan kepercayaan timbal balik antara sekolah dan publik melalui informasi yang memadai dan menjamin kemudahan dalam memperoleh informasi yang akurat (Hamid, 2007).

b. Upaya-Upaya Peningkatan Transparansi

Upaya-upaya yang perlu dilakukan dalam meningkatkan transparansi sekolah kepada publik menurut Hamid (2007) antara lain: a) pendayagunaan berbagai jalur komunikasi baik langsung maupun tidak langsung melalui temu wicara maupun media cetak maupun elektronik; b) menyiapkan kebijakan yang jelas tentang cara mendapatkan informasi, bentuk informasi yang dapat 
diakses publik dan informasi yang bersifat rahasia; c) membuat prosedur pengaduan apabila informasi tidak sampai ke publik; d) membuat peraturan yang menjamin hak publik untuk mendapatkan informasi sekolah, fasilitas data base dan sarana informasi dan komunikasi.

\section{c. Indikator Keberhasilan Transparansi}

Hamid (2007), bahwa keberhasilan transparansi sekolah ditunjukkan oleh indikator sebagai berikut: a) meningkatnya keyakinan dan kepercayaan publik kepada sekolah bahwa sekolah adalah bersih dan berwibawa; b) partisipasi publik dalam penyelenggaraan sekolah; c) bertambahnya wawasan dan pengetahuan publik; dan d) berkurangnya pelanggaran terhadap peraturan perundang-undangan.

\section{Akuntabilitas}

Secara harafiah, akuntabilitas dapat diartikan sebagai kemampuan menunjukkan laporan atau catatan yang dapat dipertanggungjawabkan (Suharto, 2005).

Menurut Jalal dan Supriadi (2001), ada tiga aspek yang dapat memberi jaminan mutu suatu lembaga pendidikan, yaitu kompetensi, akreditasi, dan akuntabilitas. Dharma (2007) menuliskan tiga pilar utama prasyarat terbangunnya akuntabilitas yaitu: (1) transparansi para penyelenggara sekolah dengan menerima masukan dan mengikutsertakan berbagai komponen dalam mengelola sekolah, (2) standar kinerja di setiap institusi dapat diukur dalam melaksanakan tugas, fungsi, dan wewenangnya, dan (3) partisipasi untuk saling menciptakan suasana kondusif dalam menciptakan pelayanan masyarakat dengan prosedur tidak sulit, biaya tidak mahal, dan pelayanan yang cepat.

\section{a. Tujuan Akuntabilitas}

Mardiasmo (2002) menyatakan tujuan utama akuntabilitas adalah untuk mendorong terciptanya akuntabilitas kinerja sekolah sebagai salah satu syarat untuk terciptanya sekolah yang baik dan terpercaya.

\section{b. Dimensi Akuntabilitas}

Ada empat dimensi akuntabilitas yang harus dipenuhi organisasi sektor publik (Mardiasmo, 2002): a) akuntabilitas kejujuran dan akuntabilitas hukum, b) akuntabilitas proses, c) akuntabilitas program, dan d) akuntabilitas kebijakan.

\section{c. Upaya-upaya Peningkatan Akuntabilitas}

Menurut Hamid (2007), delapan hal yang harus dikerjakan oleh sekolah untuk peningkatan akuntabilitas: 1) menyusun aturan main tentang sistem akuntabilitas; 2) menyusun pedoman tingkah laku dan sistem pemantauan kinerja penyelenggara sekolah dan sistem pengawasan dengan sanksi yang jelas dan tegas; 3) menyusun rencana pengembangan sekolah dan menyampaikan kepada publik/stakeholders di awal setiap tahun anggaran; 4) menyusun indikator yang jelas tentang pengukuran kinerja sekolah dan disampaikan kepada stakeholders; 5) melakukan pengukuran pencapaian kinerja pelayanan pendidikan dan menyampaikan hasilnya kepada publik/stakeholders di akhir tahun; 6) memberikan tanggapan terhadap pertanyaan dan pengaduan publik; 7) menyediakan informasi kegiatan sekolah kepada publik yang akan memperoleh pelayanan pendidikan; dan 8) memperbaharui rencana kinerja yang baru sebagai kesepakatan komitmen baru.

\section{d. Indikator Keberhasilan Akuntabilitas}

Indikator keberhasilan akuntabilitas (Hamid, 2007) sebagai berikut: 1) meningkatnya kepercayaan dan kepuasan publik terhadap sekolah; 2) tumbuhnya kesadaran publik tentang hak untuk menilai terhadap penyelenggaraan pendidikan di sekolah; 3) meningkatnya kesesuaian kegiatan-kegiatan sekolah dengan nilai dan norma yang berkembang di masyarakat; dan 4) berkurangnya kasus-kasus Korupsi Kolusi Nepotisme (KKN) di sekolah.

\section{Hipotesis}

$\mathrm{H}_{1}$ : Persepsi guru tentang kepemimpinan transformasional Kepala Sekolah berpe- 
ngaruh positif terhadap transparansi pengelolaan keuangan sekolah.

$\mathrm{H}_{2}$ : Persepsi guru tentang kepemimpinan transformasional Kepala Sekolah berpengaruh positif terhadap akuntabilitas pengelolaan keuangan sekolah.

\section{Kerangka Berfikir}

Kerangka pemikiran yang diajukan dalam penelitian ini adalah disajikan sebagai berikut:

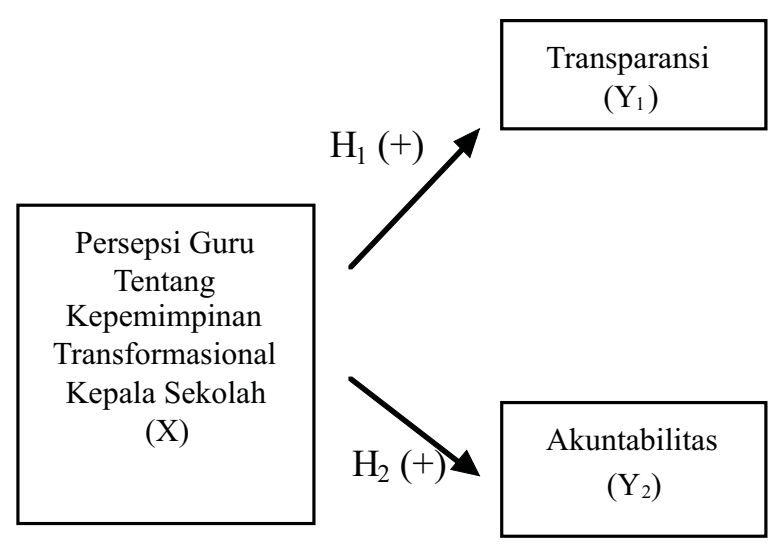

Gambar 1

Kerangka Pemikiran Penelitian

Keterangan:

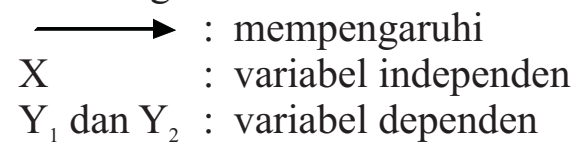

\section{METODE}

Populasi dalam penelitian ini adalah seluruh guru SMA, SMK, dan MA negeri di Kota Madiun yang berjumlah 753 orang. Kuesioner yang disebar kepada responden secara langsung sebanyak 144 kuesioner tetapi yang kembali 133 kuesioner dan layak untuk dianalisis berjumlah 120 kuestioner.

Teknik pengambilan sampel yang digunakan pada penelitian ini menggunakan purposive sampling, yaitu pengambilan sampel dengan menggunakan kriteria-kriteria yang ditentukan berdasarkan kebijakan dari peneliti.

\section{Analisis Data}

Analisis data dilakukan dengan peng- ujian hipotesis dengan menggunakan program Statistical Product and Service Solutions (SPSS).

\section{Hasil Analisis Data}

Berdasarkan data primer yang telah ada, dilakukan uji asumsi klasik sebagai persyaratan layak atau tidak layak kelompok data memenuhi kriteria uji statistik. Berikut ini uji instrumen dan persyaratan asumsi klasik sebagai syarat untuk melakukan uji regresi linear.

\section{Hasil Uji Validitas}

Hasil Uji Validitas Transparansi Pengelolaan Keuangan Sekolah $\left(\mathrm{Y}_{1}\right)$ sebanyak dua belas (12) butir soal semuanya valid. Hasil Uji Validitas Akuntabilitas Pengelolaan Keuangan Sekolah $\left(\mathrm{Y}_{2}\right)$ sebanyak empat belas (14) butir soal semuanya valid (koefisien di atas 0,361). Sehingga data tersebut dapat digunakan semua untuk keperluan analisis penelitian.

\section{Hasil Uji Reliabilitas}

Uji reliabilitas pada penelitian ini dilakukan dengan menggunakan rumus alpha cronbach. Apabila nilai alpha cronbach lebih dari 0,6 maka instrument dikatakan reliabel Nunally (1978). Hasil uji reliabitas variable $\mathrm{X}, \mathrm{Y}_{1}$, dan $\mathrm{Y}_{2}$ masing-masing adalah 0,880 , 0,825 dan 0,873 maka semua dinyatakan reliable.

\section{Hasil Uji Asumsi Klasik}

a. Hasil Uji Normalitas

Uji normalitas data dilakukan dengan menggunakan uji non parametrik, yaitu Kolmogorov Smirnov Test (K-S Test). Dari hasil analisis pengujian diketahui bahwa nilai $p$-value untuk masing-masing variabel lebih besar dari nilai cut off sebesar 0,05 yaitu $\mathrm{X}$, $\mathrm{Y}_{1}$, dan $\mathrm{Y}_{2}$ adalah $0,723,1,143$, dan 0,801 yang berarti memenuhi syarat normalitas (Ghozali, 2011). 
b. Hasil Uji Multikolinieritas

Hasil analisis Varian Inflation Factor (VIF) pada Model 1 dan Model 2 diperoleh nilai masing-masing adalah 1 , berarti kurang dari 10 sehingga dapat dikatakan bahwa masing-masing komponen dari variabel independen tidak saling berhubungan (Ghozali, 2011).

c. Hasil Uji Heteroskedastisitas

Berdasarkan nilai $p$-value pada Model 1 dan Model 2 diperoleh nilai sebesar 0,717 dan 0,807 lebih dari cut off 0,05 sehingga dapat dikatakan bahwa tidak terjadi heteroskedastisitas.

\section{d. Hasil Uji Autokorelasi}

Hasil uji Durbin Watson Test terhadap Model 1 dan Model 2 diperoleh nilai 1,491 dan 1,533, sehingga dapat dikatakan bahwa tidak terjadi Autokorelasi

\section{Hasil Pengujian Hipotesis}

a. Regresi Linear Sederhana

Dari kedua model regresi linear sederhana diperoleh Model 1 yaitu $\mathrm{Y}_{1}=12,373+$ $0,452 X$ seperti dan Model 2 yaitu $Y_{2}=21,92+$ $0,374 X$.

Tabel 1

Hasil Uji Hipotesis Model 1 dengan Uji t, F, dan $\mathbf{R}^{2}$

\begin{tabular}{|c|c|c|c|c|}
\hline Variable & Coefficient & $\begin{array}{c}\text { Std. } \\
\text { Error }\end{array}$ & $\mathrm{t}$ & Sig. \\
\hline $\begin{array}{l}\text { (Constant) } \\
\text { Kepemimpinan }\end{array}$ & 12.373 & 3.49 & 3.545 & .001 \\
\hline Transformasional & 0.452 & .065 & 6.995 & .00 \\
\hline$R$-square & 0.293 & Squares & & 3440.367 \\
\hline $\begin{array}{l}\text { Adjusted R- } \\
\text { squared } \\
\text { S. E of the }\end{array}$ & 0.287 & \multicolumn{2}{|c|}{ Mean Square } & 20.609 \\
\hline Estimate & 4.539 & \multicolumn{2}{|l|}{$\mathrm{F}$} & 48.937 \\
\hline Durbin-Watson & 1.491 & \multicolumn{2}{|l|}{ Sig. } & 0,000 \\
\hline
\end{tabular}

Sumber: data primer diolah, 2014
Tabel 2

Hasil Uji Hipotesis Model 2 dengan

Uji t, F, dan $\mathbf{R}^{2}$

\begin{tabular}{lclcc}
\hline \multicolumn{1}{c}{ Variable } & Coefficient & $\begin{array}{l}\text { Std. } \\
\text { Error }\end{array}$ & $\mathrm{t}$ & Sig. \\
\hline $\begin{array}{l}\text { (Constant) } \\
\text { Kepemimpinan } \\
\text { Transformasional }\end{array}$ & 0.374 & 0.084 & 4.475 & 0 \\
\hline $\begin{array}{l}R \text {-square } \\
\text { Adjusted } R \text { - }\end{array}$ & 0.145 & $\begin{array}{l}\text { Sum of } \\
\text { Squares }\end{array}$ & 4768 \\
$\begin{array}{l}\text { squared } \\
\text { S. E of the } \\
\begin{array}{l}\text { Estimate } \\
\text { Durbin-Watson }\end{array}\end{array}$ & 0.138 & Mean Square & 34.54 \\
\hline
\end{tabular}

Sumber: data primer diolah, 2014

\section{b. Hasil Uji t(Uji Koefisien Parsial)}

Pada Model 1 dengan nilai uji t sebesar 6,995 lebih besar dari t tabel $=1,657$ seperti pada Tabel 1 dan Model 2 dengan nilai uji $t$ sebesar 4,475 lebih besar dari t tabel $=1,657$ seperti pada Tabel 2.

c. Hasil Uji F

Berdasarkan hasil analisis dengan program SPSS diperoleh nilai uji F Model 1 sebesar 48,937 $(0,000)$ seperti pada Tabel 1 dan nilai uji F Model 2 sebesar 20,030 $(0,000)$ seperti pada Tabel 2.

\section{d. Hasil Uji R}

Tabel 1 menunjukkan hasil uji koefisien determinasi pada Model 1 dapat dilihat dari nilai Adjusted $R$ Square sebesar 0,287 menunjukkan bahwa variasi $\mathrm{X}$ dapat menjelaskan terhadap $\mathrm{Y}_{1}$ sebesar $28,7 \%$, sisanya sebesar 71,3\% dijelaskan oleh faktor di luar Model 1. Sedangkan pada Tabel 2 menunjukkan hasil uji koefisien determinasi pada model 2 dapat dilihat dari nilai Adjusted $R$ Square sebesar 0,138 menunjukkan bahwa variable $X$ dapat menjelaskan terhadap variabel $\mathrm{Y}_{2}$ sebesar 13,8\%, sisanya sebesar $86,2 \%$ dijelaskan oleh faktor di luar Model 2.

\section{PEMBAHASAN}

1. Kepemimpinan transformasional terhadap transparansi pengelolaan keuangan sekolah.

Transparansi pengelolaan keuangan 
sekolah diukur berdasarkan indikator: a) meningkatnya keyakinan dan kepercayaan publik kepada sekolah bahwa sekolah adalah bersih dan berwibawa; b) meningkatnya partisipasi publik dalam penyelenggaraan sekolah; c) bertambahnya wawasan dan pengetahuan publik terhadap penyelenggaraan sekolah; dan berkurangnya pelanggaran terhadap peraturan perundangundangan yang berlaku.

Hasil penelitian ini menunjukkan bahwa kepemimpinan kepala sekolah berpengaruh positif terhadap transparansi keuangan sekolah. Besarnya pengaruh kepemimpinan kepala sekolah terhadap transparansi pengelolaan keuangan sekolah dapat dilihat dari nilai Adjusted $R$ Square sebesar 0,287 menunjukkan bahwa variabel kepemimpinan transformasional kepala sekolah (X) dapat menjelaskan terhadap variabel transparansi dalam pengelolaan keuangan sekolah $\left(\mathrm{Y}_{1}\right)$ sebesar $28,7 \%$, sisanya sebesar $71,3 \%$ dijelaskan oleh faktor di luar model ini.

Hal ini dapat dikatakan bahwa kepala sekolah memiliki peran yang sangat strategis dalam mengelola dan mengatur kebijakan yang ada di sekolah. Di antara kepemimpinan yang dikenal memiliki banyak kelebihan adalah kepemipinan transformasional (Bass dan Avolio, 1992). Adanya kepemimpinan kepala sekolah yang baik, terutama dengan kepemimpinan transformasional, maka akan memberikan pengaruh terhadap setiap kegiatan yang dilaksanakan di lingkungan sekolah. Hal itu juga termasuk berpengaruh pada keterbukaan (transparansi) sekolah dalam mengelola keuangan.

Transparansi keuangan sangat diperlukan dalam rangka meningkatkan dukungan orang tua, masyarakat dan pemerintah dalam penyelenggaraan seluruh program pendidikan di sekolah (Dharma, 2007). Di samping itu, transparansi dapat menciptakan kepercayaan timbal balik antara pemerintah, masyarakat, orang tua siswa dan warga sekolah melalui penyediaan informasi dan menjamin kemudahan di dalam memperoleh informasi yang akurat dan memadai.

Demikian, secara teoritis dan kenyataan dapat disimpulkan bahwa kepemimpinan transformasional kepala sekolah berpengaruh terhadap transparansi dalam pengelolaan keuangan sekolah (hipotesis diterima).

2. Kepemimpinan transformasional terhadap akuntabilitas pengelolaan keuangan sekolah

Akuntabilitas pengelolaan keuangan sekolah diukur berdasarkan indikator: a) meningkatnya kepercayaan dan kepuasan publik terhadap sekolah; b) tumbuhnya kesadaran publik tentang hak untuk menilai terhadap penyelenggaraan pendidikan di sekolah; dan c) meningkatnya kesesuaian kegiatan-kegiatan sekolah dengan nilai dan norma yang berkembang di masyarakat.

Hasil penelitian ini menunjukkan bahwa kepemimpinan transformasional kepala sekolah berpengaruh positif terhadap akuntabilitas pengelolaan keuangan sekolah. Besarnya pengaruh tersebut secara statistik dapat dilihat dari nilai Adjusted $R$ Square sebesar 0,138 menunjukkan bahwa variasi komponen variabel kepemimpinan transformasional kepala sekolah (X) dapat menjelaskan terhadap variabel akuntabilitas pengelolaan keuangan sekolah $\left(\mathrm{Y}_{2}\right)$ sebesar $13,8 \%$, sisanya sebesar $86,2 \%$ dijelaskan oleh faktor di luar model ini.

Hubungan kepemimpinan sebagai variabel independen (bebas) dan akuntabilitas sebagai variabel dependen (terikat) dapat dijelaskan sebagai berikut. Kepala sekolah sebagai pimpinan lembaga memegang peran yang besar dalam menentukan kebijakan yang ditetapkan oleh sekolah. Kepala sekolah dalam menentukan kebijakan yang dibuat sangat dipengaruhi oleh kepemimpinannya.

Secara mendasar kelebihan kepemimpinan transaksional adalah dapat memotivasi bawahan secara individu dan meningkatkan kinerja pegawai secara individu. Namun demikian, kepemimpinan transaksional memiliki kelemahan. Kelemahan kepemimpinan 
transaksional adalah munculnya persaingan individu dalam sebuah lembaga. Kepemimpinan transformasional merupakan kepemimpinan dimana pemimpin terampil dalam memimpin (leading), memperjuangkan perubahan (championing change), dan mengubah organisasi (transforming organizations) (Warrick, 2011).

Kepemimpinan transformasional memiliki empat karakteristik utama yakni: idealized influence (pengaruh idealis), inspirational motivation (motivasi inspirasional), intellectual stimulation (stimulasi intelektual), dan individual consideration (pertimbangan individu) (Bass dan Avolio, 1992). Dengan adanya keempat faktor kepemimpinan tersebut diharapkan dapat meningkatkan kinerja sebuah sebuah lembaga termasuk sekolah. Di antara hal yang diharapkan baik sebagai dampak kepemimpinan transformasional adalah pada proses pelaporan keuangan sekolah, termasuk di dalam proses pelaporan tersebut adalah akuntabilitas.

Akuntabilitas keuangan sebagai bagian sifat pokok dari pertanggungjawaban pengelolaan sumber daya serta pelaksanaan kebijakan yang dipercayakan kepada entitas pelaporan dalam mencapai tujuan yang telah ditetapkan sekolah secara periodik. Dalam pelaporan tersebut akuntabilitas keuangan yang memiliki beberapa kriteria, antara lain: adanya pertanggungjawaban dana publik, penyajian yang disampaikan tepat pada waktunya, dan adanya pemeriksaan (audit/ respon) pemerintah dalam pengelolaan keuangan sekolah. Kelancaran dan baiknya akuntabilitas keuangan sekolah tersebut dipengaruhi oleh banyak faktor. Kepala sekolah sebagai pimpinan di lingkungan sekolah memiliki pengaruh terhadap pengelolaan semua aset sekolah, termasuk pengelolaan keuangan.

Dari berbagai penelitian dan kajian menunjukkan adanya keterkaitan penerapan kepemimpinan - kepala sekolah terhadap akuntabilitas pengelolaan keuangan sekolah.
Dengan demikian, secara teoritis dan kenyataan dapat disimpulkan bahwa kepemimpinan transformasional kepala sekolah berpengaruh terhadap akuntabilitas dalam pengelolaan keuangan sekolah (hipotesis diterima).

\section{PENUTUP}

\section{Simpulan}

Berdasarkan deskripsi data penelitian dan analisis data hubungan antara persepsi guru tentang kepemimpinan transformasional kepala sekolah dengan transparansi dan akuntabilitas keuangan sekolah, dapat disimpulkan sebagai berikut:

1. Persepsi guru tentang kepemimpinan transformasional kepala sekolah berpengaruh positif terhadap transparansi dalam pengelolaan keuangan sekolah.

2. Persepsi guru tentang kepemimpinan transformasional kepala sekolah berpengaruh positif terhadap akuntabilitas dalam pengelolaan keuangan sekolah.

\section{Saran}

Saran yang dapat peneliti berikan secara umum dapat penulis uraikan sebagai berikut:

1. Peneliti dan pembaca

a. Peneliti selanjutnya hendaknya memperluas populasi penelitian tidak hanya di Kota Madiun, namun se wilayah Propinsi Jawa Timur atau Indonesia. Demikian juga responden meliputi sekolah negeri maupun swasta.

b. Peneliti selanjutnya menggunakan metode wawancara, sehingga data yang diperoleh lebih akurat.

c. Peneliti selanjutnya menggunakan variabel selain yang telah diteliti dalam penelitian ini. Misalnya, penelitian selanjutnya dapat menguji pengaruh status sekolah (negeri dan swasta) terhadap akuntabilitas dan transparansi pengelolaan keuangan sekolah.

2. Pengelola keuangan sekolah

Pihak pengelola keuangan sekolah yang 
menangani keuangan secara langsung harus bekerja secara profesional, selalu menjaga komunikasi dan memberikan masukan kepala sekolah, karena kepemimpinan sekolah sangat berperan dalam pengelolaan keuangan sekolah. Apapun bentuk dan kepemimpinan kepala sekolah hendaknya pengelola keuangan sekolah tetap melakukan hal-hal pokok yang berkaitan dengan tugasnya secara standar dan sesuai prosedur. Dengan demikian, diharapkan pengelolaan keuangan sekolah akan tetap transparan dan akuntabel.

\section{DAFTAR PUSTAKA}

Amstrong, M. (2002). Performance Management. New York: Kogan Page Ltd.

Anggraini, R.D. (2013). Transparansi, Partisipasi, dan Akuntabilitas Pengelolaan Anggaran Dana BOS Dalam Program RKAS di SDN Pacarkeling VIII Surabaya. Kebijakan dan Manajemen Publik FISIP, Universitas Airlangga 1(2), 201-208.

Anwar, Prabu. (2005). Pengaruh Motivasi Terhadap Kepuasan Kerja Pegawai Badan Koordinasi Keluarga Berencana Nasional Kabupaten Muara Enim. Jurnal Manajemen dan Bisnis Sriwijaya 3(6), 1-12.

Bass, B.M., dan Avolio, B.J. (1992). Improving Organizational Effectiveness through Transformational Leadership. Thousand Oaks, CA: Sage.

Boy, D. dan Siringoringo, H. (2009). Analisis Pengaruh Akuntabilitas dan Transparansi Pengelolaan Anggaran Pendapatan dan Belanja Sekolah (APBS) terhadap Partisipasi Orang Tua Murid. Jurnal Ekonomi Bisnis Universitas Gunadarma 14(12), 79-87.
Budiardjo, Miriam. (1998). Partisipasi dan Partai Politik. Jakarta: Gramedia.

Burns, J.M. (1978). Leadership. New York: Harper and Row.

Bycio, P., Hackett, R.D., dan Allen, J.S. (1995). Further Assessments of Bass's (1985). Conceptualization of Transactional and Transformational Leadership. Journal of Applied Psychology, 80 (4), 468-478.

Cobb, D.A., Clark dan Jha, N. (2013). Educational Achievement and the Allocation of School Resources. Melbourne Institute Working Paper No. 27 (13), 1-36.

Dharma, Agus. (2003). Manajemen Supervisi: Petunjuk Praktis Bagi Para Supervisor. Jakarta: Raja Grafindo Persada.

Dharma, Surya. (2007). Manajemen Kinerja. Edisi Ketiga. Yogyakarta: Pustaka Pelajar.

Eric, A.H. and Margaret, E.R. (2006). School Accountability and Student Performance. Federal Reserve Bank of St. Louis. Regional Economic Development, 2(1), 51-61.

Fullan, M. (2005). Turnaround leadership. The Educational Forum, (69), 174-181.

Ghozali, Imam. (2011). Aplikasi Analisis Multivariate dengan Program SPSS. Semarang: Badan Penerbit Universitas Diponegoro.

Givens, R.J. (2008). Transformational Leadership: The Impact on Organizational and Personal Outcomes. Emerging Leadership Journeys, 1 (1), 4-24.

Hall. J, Johnson S., Wysocki A., and Kepner. K. (2012). Transformational Leadership: The Transformation of Managers 
and Associates. Florida Cooperative Extension Service, Institute of Food and Agricultural Sciences. University of Florida.

Hamid, Muhammad. (2007). Manajemen Berbasis Sekolah (MBS). Jakarta: Direktorat Pembinaan Sekolah Menengah Pertama.

Jawa Pos, Radar Madiun. (2014). Jaksa Pakai Jurus Pukul Rata. Rabu, 19 Maret 2014.

Keller, R.T. (1992). Transformational Leadership and the Performance of Research and Development Project Groups. Journal of Management, 18 (3), 489-501.

Komariah, A. dan Triatna, C. (2006). Visionary Leadership; Menuju Sekolah Efektif. Jakarta: Bumi Aksara.

Lee, A.P. dan McWilliam, E. (2007). Accountability, Responsibility and school leadership. Journal of Educational Enquiry, 7 (1), 32-43.

Ling, S.L.M. and Ibrahim, M.S. (2013). Transformational Leadership and Teacher Commitment in Secondary Schools of Sarawak. Faculty of Education, University of Malaya, Malaysia. International Journal of Independent Research and Studies, 2 (2), 51-65.

Mardiasmo. (2002). Akuntansi Sektor Publik. Yogyakarta: Penerbit Andi.

Mulyasa. (2003). Manajemen Berbasis Sekolah. Konsep, Strategi dan Implementasi. Bandung: PT. Remaja Rosdakarya Offset.

Nuraeni, Y., Suhartati, T., dan Rahman, A. (2012). Model Pengelolaan Keuangan Instansi dalam Mewujudkan Transparansi dan Akuntabilitas Keuangan Negara. Jurnal Ekonomi dan Bisnis, 11 (1), 53-60.
Odumeru, J. A. and Ogbonna, I. G. (2013). Transformational vs. Transactional Leadership Theories: Evidence in Literature. International Review of Management and Business Research, 2 (2):355-361.

Onorato, M. (2013). Transformational Leadership Style in The Educational Sector: An Empirical Study of Corporate Managers and Educational Leaders. Academy of Educational Leadership Journal, 17(1),33-47.

Peraturan Menteri Pendidikan Nasional Republik Indonesia No. 19 Tahun 2007. Tentang Standar Pengelolaan Pendidikan oleh Satuan Pendidikan Dasardan Menengah.

Salama, A., Cathcart, A., Andrews, M. \& Hall, R. (2006). Disclosure Regulation and Accounting Education in the UK: Moving Towards Corporate Accountability and Transparency. Social Responsibility Journal, 2 (3), 251-260.

Sekaran, Uma dan Bougie, Roger. 2009. Research Methods for Business: A Skill Building Approach. Fifth Edition. New York: John Wiley \& Sons, Inc.

Simic, I. (1998). Transformasional Leadership - The Key to Successful Management of Transformasional Organization Change. The Scientific journal Facta Universitatis Series: Economics and Organization, 1 (6), 4955.

Suharto, Edi. (2005). Analisis Kebijakan Publik: Panduan Praktis Mengkaji. Bandung: PT. Remaja Rosdakarya Offset.

Undang-Undang Republik Indonesia No. 20 Tahun 2003 Tentang Sistem Pendidikan Nasional. Jakarta: CV. Tamita Utama.

Undang-Undang Republik Indonesia No. 17 Tahun 2003. Tentang Keuangan Negara. 
Undang-Undang Republik Indonesia No. 32 tahun 2004. Tentang Pemerintahan Daerah.

Warrick, D. D. (2011). The Urgent Need for Skilled Transformational Leaders: Integrating Transformational Leader- ship and Organization Development. Journal of Leadership, Accountability and Ethics, 8(5).

Zamroni. (2000). Paradigma Pendidikan Masa Depan, Jogjakarta: Bigraf Publishing. 